\title{
34. REGIONAL ASPECTS OF DEEP SEA DRILLING IN THE WESTERN INDIAN OCEAN, LEG 25, DSDP
}

\author{
R. Schlich, Institut de Physique du Globe de Paris, Saint-Maur-des-Fossés, France \\ E. S. W. Simpson, University of Capetown, Rondebosch, South Africa \\ and \\ T. L. Vallier, Scripps Institution of Oceanography, La Jolla, California
}

\section{INTRODUCTION}

The western Indian Ocean is bounded on the north and northwest by India and Africa. A long linear topographic structure, the Ninetyeast Ridge, which extends from north of the equator to about $30^{\circ} \mathrm{S}$, forms its eastern boundary. To the south, beyond the active oceanic ridge system, the Indian Ocean is limited by the Antarctic continent. The western Indian Ocean is dominated by a complex system of seismically active mid-oceanic ridges that extend from the Gulf of Aden towards the Mascarene Islands where the system splits into two distinct ridges that separate Antarctica from the African and Australian continents. Another dominant characteristic of the western Indian Ocean is the large number of submarine plateaus, also designated as aseismic ridges, sometimes extremely wide, not necessarily capped by islands, and with a preferred north-south trend. These aseismic ridges have been interpreted either as uplifted oceanic crust (e.g. Ninetyeast Ridge), as volcanic edifices (Mascarene Plateau, ChagosLaccadive Ridge), or as continental fragments (KerguelenHeard Plateau, Madagascar Ridge, Mozambique Ridge, Crozet Plateau). In fact, at the present time, except for the well-known Seychelles Bank (Baker, 1963; Baker and Miller, 1963; and Matthews and Davies, 1966) and, perhaps, for part of the Kerguelen-Heard Plateau (Schlich et al., 1971), there is no evidence to favor a continental structure, particularly for the Madagascar and Mozambique ridges and the Crozet Plateau.

In this concluding chapter we shall discuss certain regional aspects in the western Indian Ocean that have a bearing on the geologic history. Although many of the interpretations given are derived from data obtained by drilling on Leg 25 (see track chart and site locations on Figure 1, stratigraphic columns on Figure 2, and coring summary in Table 1), we also have used data acquired from several other cruises in the western Indian Ocean.

In order to explain some of the reasons for specific site selections, a review of the Leg 25 objectives is given first. However, the major purpose of this chapter is to develop a geologic history of the region as we interpret it from a study of magnetic anomalies and deep-sea drilling results. Magnetic anomaly patterns are used as the framework for this development. A discussion of these patterns is followed by an interpretation of the drilling results within this framework. To better understand the time relationships, we have included both the absolute and geomagnetic time scales that are used in this volume (Figures 3 and 4). The paleoposition of Madagascar has been a subject of controversy for several years and, consequently, some of the drilling results will be discussed which have a bearing on this problem. The last part of this chapter summarizes the data acquired from each site and includes some of the major conclusions of other contributors to this volume. We wish to emphasize that chapters in Part II and the two chapters which precede this one in Part III contain many interpretations that we cannot summarize in this chapter.

\section{OBJECTIVES OF DRILLING IN THE WESTERN INDIAN OCEAN}

Leg 25 of the Glomar Challanger was the fourth of six legs devoted to reconnaissance deep-sea drilling into the floor of the Indian Ocean. The site locations for this leg and the tracks followed by Glomar Challenger are shown in Figure 1. While subject to the severe logistic limitations imposed upon reconnaissance studies in a large area, Leg 25 of the Deep Sea Drilling Project provided the first opportunity to study the relatively unknown basins and the seismic and aseismic ridges which are situated in the vicinity of Madagascar. The carefully planned program of drilling was not fully accomplished due to a variety of unforeseen factors including a major mid-leg change in drilling program which originated from the JOIDES Indian Ocean Panel. The eight sites which were successfully drilled out of eleven occupied are located in a variety of apparently unrelated tectonic, sedimentologic, and morphologic provinces in the structurally complex western part of the Indian Ocean (Laughton et al., 1970).

In light of the changes noted above, which were dictated by circumstances beyond our control, the modified objectives of the holes drilled during Leg 25 can best be summarized as follows:

a) To check the magnetic anomaly pattern proposed by Schlich and Patriat (1971c) in the Madagascar Basin (Site 245) and to verify whether the magnetic anomaly pattern mapped by McKenzie and Sclater (1971) north of the Seychelles Islands in the Somali Basin can be extrapolated to the south (Site 240).

b) To provide basement age in the Mascarene (Site 239) and Mozambique (Site 248) basins in order to guide further investigations and interpretation of magnetic anomalies.

c) To determine the age and mode of formation of the western Somali Basin and its western margin on the east Africa continental rise near Kenya (Sites 240 and 241).

d) To determine the significance of the Davie Ridge in relation to possible movements of Madagascar relative to Africa (Site 242).

e) To establish the thickest possible stratigraphic column in the Mozambique Channel so as to guide further 


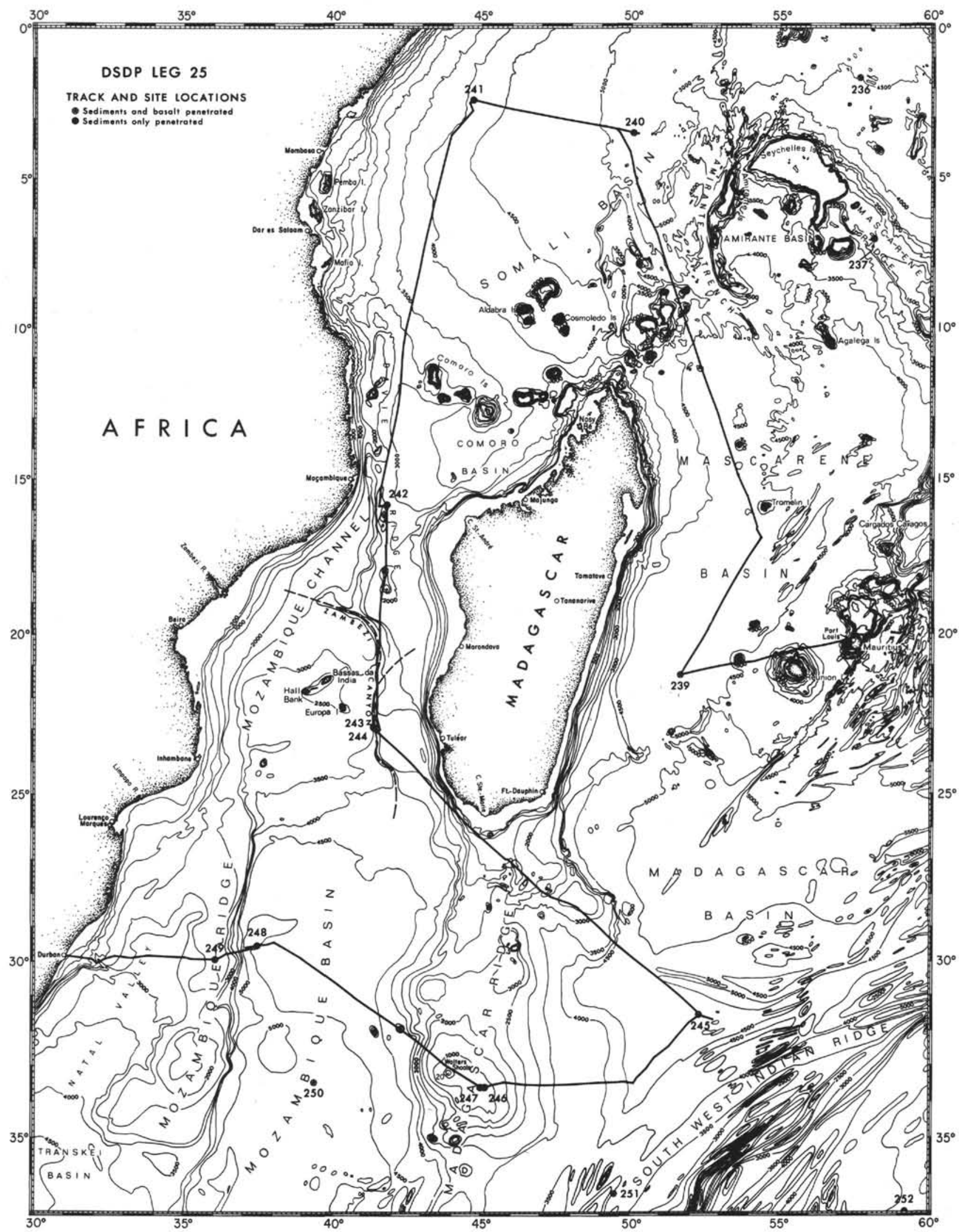

Figure 1. DSDP Leg 25 track chart and drilling site locations in relation to major sea-floor morphological features. 


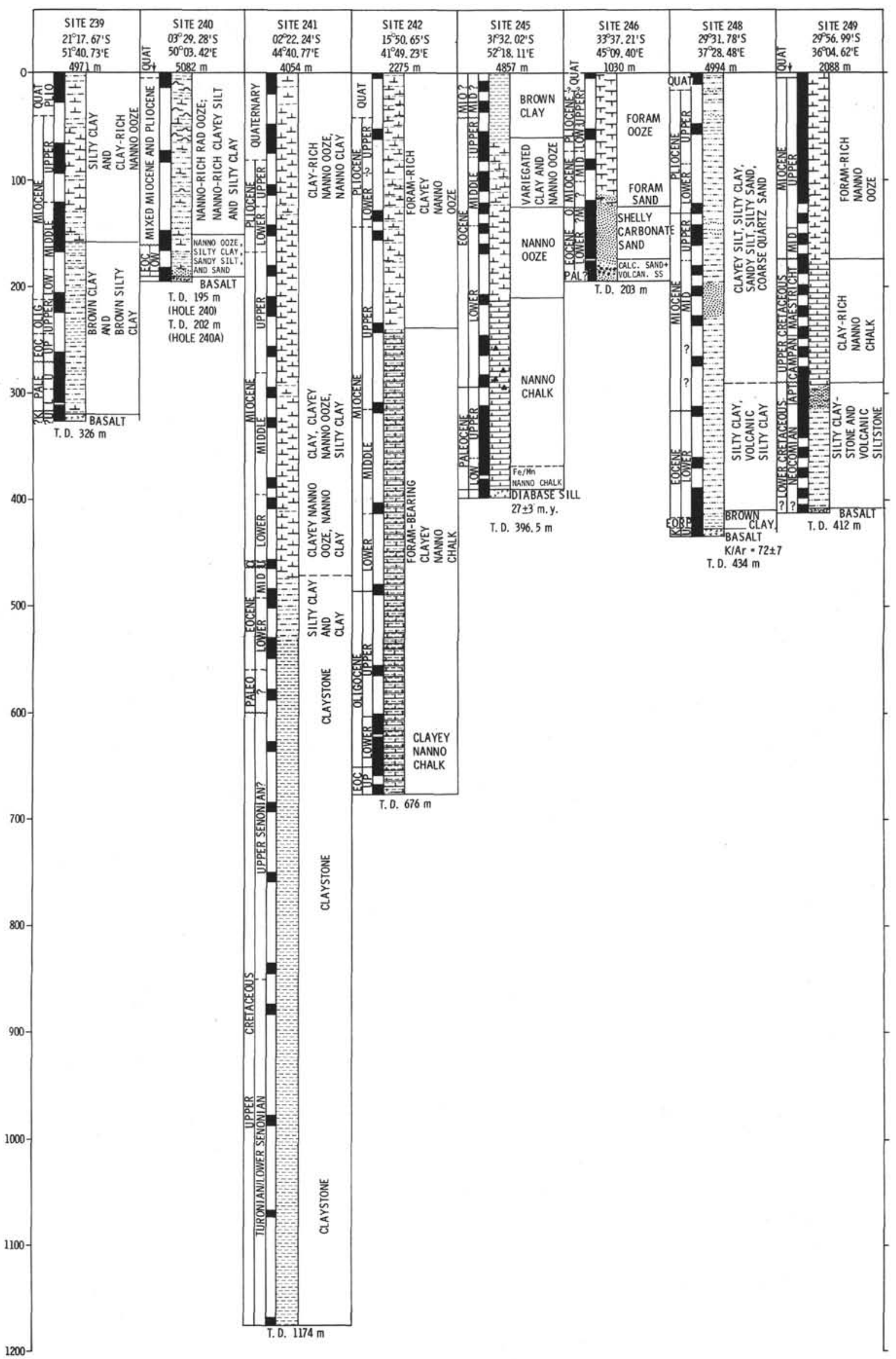

Figure 2. DSDP Leg 25 stratigraphic columns. 
TABLE 1

Coring Summary, Leg 25

\begin{tabular}{|c|c|c|c|c|c|c|c|c|}
\hline Hole & $\begin{array}{l}\text { Dates } \\
(1972)\end{array}$ & Location & $\begin{array}{l}\text { Water } \\
\text { Depth } \\
\text { (m) }\end{array}$ & $\begin{array}{l}\text { Subbottom } \\
\text { Penetration } \\
\text { (m) }\end{array}$ & $\begin{array}{c}\text { Cores } \\
\text { (m) }\end{array}$ & $\begin{array}{c}\text { Cored } \\
(\mathrm{m})\end{array}$ & $\begin{array}{l}\text { Recovered } \\
\text { (m) }\end{array}$ & $\begin{array}{c}\text { Recovery } \\
(\%)\end{array}$ \\
\hline $\begin{array}{l}239 \\
240 \\
240 \mathrm{~A} \\
241\end{array}$ & $\begin{array}{l}\text { 30 June-3 July } \\
9-10 \text { July } \\
\text { 11-12 July } \\
13-18 \text { July }\end{array}$ & $\begin{array}{l}21^{\circ} 27.67^{\prime} \mathrm{S}, 51^{\circ} 40.73^{\prime} \mathrm{E} \\
03^{\circ} 29.28^{\prime} \mathrm{S}, 50^{\circ} 03.42^{\prime} \mathrm{E} \\
03^{\circ} 29.28^{\prime} \mathrm{S}, 50^{\circ} 03.42^{\prime} \mathrm{E} \\
02^{\circ} 22.24^{\prime} \mathrm{S}, 44^{\circ} 40.77^{\prime} \mathrm{E}\end{array}$ & $\begin{array}{l}4971 \\
5082 \\
5082 \\
4054\end{array}$ & $\begin{array}{r}326 \\
195 \\
202 \\
1174\end{array}$ & $\begin{array}{r}21 \\
8 \\
4 \\
29\end{array}$ & $\begin{array}{r}175 \\
53 \\
34 \\
252\end{array}$ & $\begin{array}{r}106.1 \\
25.1 \\
3.2 \\
136.7\end{array}$ & $\begin{array}{r}61 \\
47 \\
9 \\
54\end{array}$ \\
\hline $\begin{array}{l}242 \\
243 \\
244 \\
245\end{array}$ & $\begin{array}{l}\text { 23-26 July } \\
28-29 \text { July } \\
\text { 29 July } \\
\text { 2-6 August }\end{array}$ & $\begin{array}{l}15^{\circ} 50.65^{\prime} \mathrm{S}, 41^{\circ} 49.23^{\prime} \mathrm{E} \\
22^{\circ} 54.49^{\prime} \mathrm{S}, 41^{\circ} 23.99^{\prime} \mathrm{E} \\
22^{\circ} 55.87^{\prime} \mathrm{S}, 41^{\circ} 25.98^{\prime} \mathrm{E} \\
31^{\circ} 32.02^{\prime} \mathrm{S}, 52^{\circ} 18.11^{\prime} \mathrm{E}\end{array}$ & $\begin{array}{l}2275 \\
3879 \\
3768 \\
4857\end{array}$ & $\begin{array}{r}676 \\
32 \\
27 \\
397\end{array}$ & $\begin{array}{r}19 \\
1 \\
1 \\
19\end{array}$ & $\begin{array}{r}134 \\
6 \\
3 \\
151\end{array}$ & $\begin{array}{r}103.1 \\
0.3 \\
0.0 \\
82.1\end{array}$ & $\begin{array}{r}77 \\
5 \\
0 \\
55\end{array}$ \\
\hline $\begin{array}{l}245 \mathrm{~A} \\
246 \\
247 \\
248 \\
249\end{array}$ & $\begin{array}{l}\text { 6-7 August } \\
9-10 \text { August } \\
10-11 \text { August } \\
13-17 \text { August } \\
17-20 \text { August } \\
\text { Total }\end{array}$ & $\begin{array}{l}31^{\circ} 32.02^{\prime} \mathrm{S}, 52^{\circ} 18.11^{\prime} \mathrm{E} \\
33^{\circ} 37.21^{\prime} \mathrm{S}, 45^{\circ} 09.60^{\prime} \mathrm{E} \\
33^{\circ} 37.53^{\prime} \mathrm{S}, 45^{\circ} 00.68^{\prime} \mathrm{E} \\
29^{\circ} 31.78^{\prime} \mathrm{S}, 37^{\circ} 28.48^{\prime} \mathrm{E} \\
29^{\circ} 56.99^{\prime} \mathrm{S}, 36^{\circ} 04.62^{\prime} \mathrm{E}\end{array}$ & $\begin{array}{r}4857 \\
1030 \\
944 \\
4994 \\
2088\end{array}$ & $\begin{array}{r}149 \\
203 \\
26 \\
434 \\
412 \\
4253\end{array}$ & $\begin{array}{r}7 \\
11 \\
1 \\
17 \\
33 \\
171\end{array}$ & $\begin{array}{r}63 \\
94 \\
8 \\
136 \\
285 \\
1394\end{array}$ & $\begin{array}{r}47.4 \\
23.8 \\
0.0 \\
40.8 \\
221.4 \\
790.0\end{array}$ & $\begin{array}{r}75 \\
25 \\
0 \\
30 \\
78 \\
57\end{array}$ \\
\hline
\end{tabular}

interpretation of the origin and structure of this feature. (This objective, for Sites 243 and 244, was unsuccessful due to insurmountable technical problems relating to hole stability.)

f) To determine if the basement of the Madagascar and Mozambique ridges are of continental or oceanic rock type and to establish on these ridges a mid-latitude biostratigraphic succession above the carbonate compensation depth (Sites 246 and 249).

\section{SEA-FLOOR SPREADING IN THE WESTERN INDIAN OCEAN}

North of $20^{\circ} \mathrm{S}$, the Central Indian Ridge follows a north-south line, between the Mascarene Plateau and the Chagos Laccadive Ridge. Approximately at the equator, this structure is prolonged in a northwest direction by the Carlsberg Ridge, which extends into the Gulf of Aden as the Sheba Ridge. Langseth and Taylor (1967), and Fisher, et al. $(1967,1968$, and 1971) have shown that these ridges are spreading in a northeast-southwest direction.

A large amount of investigative work has been done in identifying and mapping magnetic anomalies associated with these ridges. The results of some of the more significant ones are summarized on Table 2. For the Central Indian Ridge, Fisher et al. (1971) have identified and mapped young magnetic anomalies 1 to 5 (Recent to Miocene) with a spreading (half) rate of about $2 \mathrm{~cm} / \mathrm{yr}$. For the Carlsberg Ridge, Cann and Vine (1966), Vine (1966), Le Pichon and Heirtzler (1968), and Fisher et al. (1968) have identified identical magnetic anomalies with spreading (half) rates of about $1.2 \mathrm{~cm} / \mathrm{yr}$. In the Arabian Sea north of the Carlsberg Ridge, and in the Somali Basin north of the Seychelles Islands, Matthews (1966) and Fisher et al. (1968) observed clear magnetic lineations, trending east-west north of the Carlsberg Ridge and west-northwesteast-southeast south of the Carlsberg Ridge. McKenzie and Sclater (1971) have identified these lineations as corresponding to anomalies 23 to 29 (Paleocene to Late Cretaceous) and found a spreading (half) rate for these anomalies of about $6.5 \mathrm{~cm} / \mathrm{yr}$. McKenzie and Sclater (1971) suggest, according to the identifications made on both sides of the Carlsberg Ridge, in the Arabian Sea and in the Somali Basin and considering the changes of direction and the distance between the ridge crest and anomaly 28 , a very low spreading rate or even a halt in spreading from Eocene to Miocene.

Between the Chagos Laccadive Ridge and the Ninetyeast Ridge, McKenzie and Sclater (1971) have recognized in the Central Indian Basin distinctive magnetic anomalies trending in a east-west direction. They have identified these as anomalies 22 through 33 and have calculated a spreading (half) rate of about $8 \mathrm{~cm} / \mathrm{yr}$ between anomalies 22 and 30 , and about $5.6 \mathrm{~cm} / \mathrm{yr}$ for the older anomalies beyond anomaly 30 . At this time, magnetic anomalies younger than 22 were not reported by these authors. Now Sclater and Fisher (in press) have identified younger (younger than 22) anomalies in the southern part of the Central Indian Ocean Basin. Finally, they have found for the whole magnetic sequence, spreading (half) rates of $2.5 \mathrm{~cm} / \mathrm{yr}$ between anomalies 7 and $16,4.0 \mathrm{~cm} / \mathrm{yr}$ between anomalies 16 and $22,8.1 \mathrm{~cm} / \mathrm{yr}$ between anomalies 22 and $27,12.0 \mathrm{~cm} / \mathrm{yr}$ between anomalies 27 and 30 , and $5.7 \mathrm{~cm} / \mathrm{yr}$ between anomalies 30 and 33. Sclater and Fisher have also shown that this magnetic anomaly pattern is offset by several north-south trending fracture zones at $78^{\circ} \mathrm{E}, 83^{\circ} \mathrm{E}$, and $86^{\circ} \mathrm{E}$, and therefore cannot be traced east-west over very long distances.

South of $20^{\circ} \mathrm{S}$, the Southwest Indian Ridge extends from the Mascarene Islands through Marion and Prince Edward islands and is joined by the southern end of the Mid-Atlantic Ridge near Bouvet Island. The Southeast Indian Ridge extends from near the Mascarene Islands through Amsterdam and St. Paul islands and joins the Pacific Antarctic Ridge south of Australia. The magnetic anomalies and spreading rates associated with the Southwest Indian Ridge and Southeast Indian Ridge are given in Table 3. Schlich and Patriat (1971a), Bergh (1971), and McKenzie and Sclater (1971) have shown that the Southwest Indian Ridge is a nearly north-south spreading ridge offset by several fracture zones running almost north-south. They found, essentially from the axial magnetic anomaly, a spreading (half) rate of about 0.6 to 


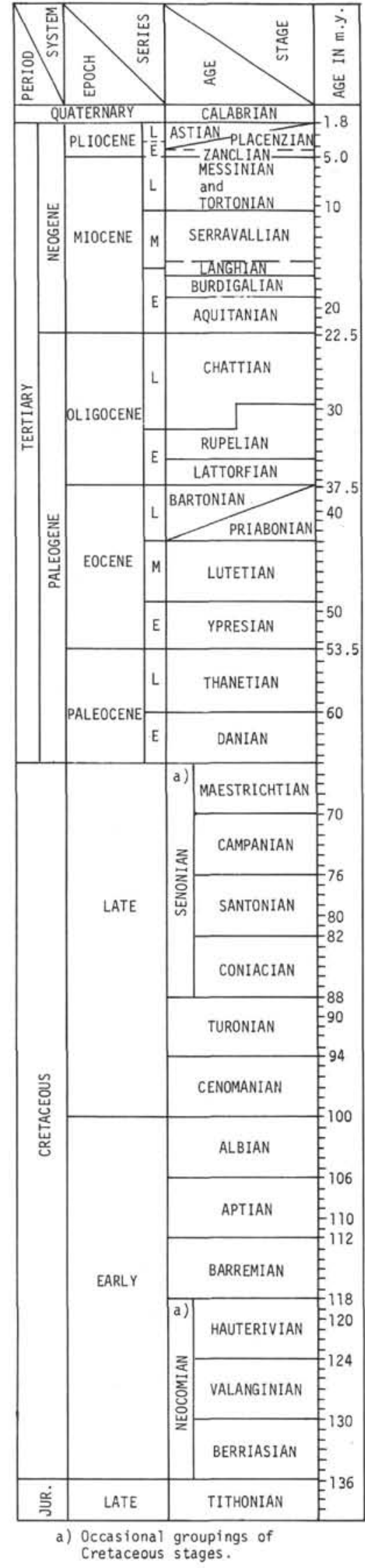

Figure 3. Absolute ages used in this volume (after Berggren (1972) for the Cenozoic and Casey (1964) for the Cretaceous).
$0.9 \mathrm{~cm} / \mathrm{yr}$. These results have been recently confirmed by drilling during Leg 26 of the Deep Sea Drilling Project (Davies, Luyendyk, et al., 1973). At Site 251 of Leg 26, which lies about $180 \mathrm{~km}$ north of the crest of the Southwest Indian Ridge, the crust was dated from nannofossils in inclusions within the basalt at 17 to 18 m.y., giving a spreading rate of about 0.9 to $1.0 \mathrm{~cm} / \mathrm{yr}$, which is in complete agreement with the above mentioned values. Schlich and Patriat (1971b and 1971c) have identified, in the Crozet Basin between Amsterdam and Kerguelen islands, anomalies 1 through 17 and have shown that the Southeast Indian Ridge has been a northeastsouthwest spreading ridge for the last 45 million years. The axial magnetic anomaly associated with the ridge crest has been clearly identified and is offset in the vicinity of Amsterdam and St. Paul islands by several northeastsouthwest trending fracture zones. Beyond anomaly 17, Schlich and Patriat (1971c) and Schlich, Patriat, and Ségoufin (1972b) observed west-northwest-east-southeast trending magnetic anomalies in the Crozet Basin which they identified as anomalies 23 to 27. Similar Paleocene to Late Cretaceous magnetic anomalies were recognized by the same authors in the Madagascar Basin (Schlich and Patriat, 1971c). The right lateral offset of the anomaly pattern, on each side of the Southwest Indian Ridge in the Crozet and Madagascar basins, is about $1000 \mathrm{~km}$. The present spreading (half) rate for the Southeast Indian Ridge is $3.4 \mathrm{~cm} / \mathrm{yr}$, but several minor changes have been recorded between Miocene and Eocene time (Schlich and Patriat, 1971b) at about 10 m.y. (anomaly 5), 19 m.y. (anomaly 5c/5d), 24 m.y. (anomaly 6a), and 45 m.y. (anomaly 18). For Paleocene time (anomalies 23 to 27), high spreading rates of about 7 to $8 \mathrm{~cm} / \mathrm{yr}$ were found in both the Crozet and Madagascar basins. These results for the Crozet Basin must be compared with the interpretation presented by McKenzie and Sclater (1971), and Sclater and Fisher (in press) for the Central Indian Basin. It is clear that these basins were formed simultaneously by spreading from the same ridge (Figure 5).

Bathymetric and magnetic data collected recently in 1972 and 1973 in the Southwestern Indian Ocean, during Gallieni cruise GA-5 in the Crozet Basin, Glomar Challenger Leg 25 in the Mascarene Basin, and Marion Dufresne cruises MD-1 and MD-2 in the Crozet, Madagascar, and Mascarene basins, have provided new clues for the interpretation of the spreading history in the Southwestern Indian Ocean.

In the Crozet Basin beyond anomaly 27, anomalies 28 through 33, offset by several north-northeastsouth-southwest fracture zones, have been clearly identified and mapped (Schlich, in preparation).

In the Madagascar and Mascarene basins (Schlich, this volume), Late Cretaceous magnetic anomalies, up to anomaly 33, have been recognized. In the Madagascar Basin, anomaly 33 lies close to the eastern slope of the Madagascar Ridge; in the Mascarene Basin, anomaly 33 is observed east of Madagascar at about $22^{\circ} \mathrm{S}$ and $50^{\circ} \mathrm{E}$. Anomalies 33,32 , and possibly 31 strike $138^{\circ} \mathrm{E}$; anomalies 30 through 23 trend $130^{\circ}$ to $127^{\circ} \mathrm{E}$. Several remarkable changes in spreading rates, similar to the changes observed by Sclater and Fisher (in press) in the Central Indian Basin, are recorded in the Madagascar and Mascarene basins between anomalies 31 and 30 (71 m.y. B.P.), near anomaly 


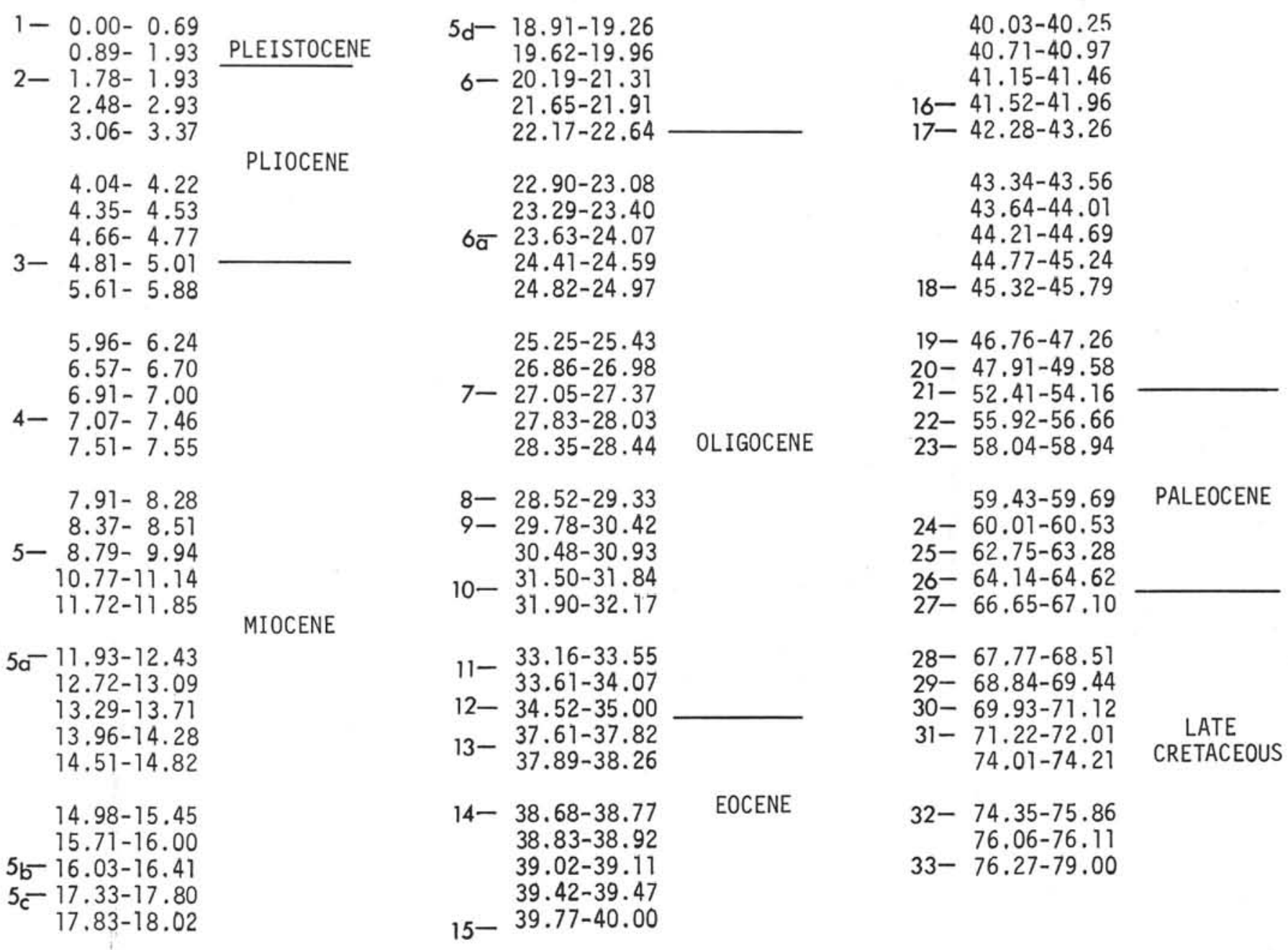

Figure 4. Geomagnetic time scale used. From left to right for each column: magnetic anomaly numbers, intervals of normal polarity (m.y.), and geological epochs.

27 (67.5 m.y. B.P.), and just before anomaly 22 (57 m.y. B.P.). The spreading (half) rates, calculated from the Heirtzler et al. (1968) time scale, complemented beyond anomaly 30 by McKenzie and Sclater (1971), are $4.0 \mathrm{~cm} / \mathrm{yr}$ for anomalies 33 to $31,12.2 \mathrm{~cm} / \mathrm{yr}$ for anomalies 30 to 28 , $7.1 \mathrm{~cm} / \mathrm{yr}$ for anomalies 27 to 33 , and about $4.0 \mathrm{~cm} / \mathrm{yr}$ after anomaly 23 . Fracture zones extending from the Madagascar Ridge and Madagascar mainland towards the Central Indian Ridge and the Mascarene Plateau have been mapped throughout the Madagascar and Mascarene basins. These fracture zones trend about $50^{\circ} \mathrm{E}$ to the south and change progressively to $38^{\circ} \mathrm{E}$. Near anomaly 22 in the Madagascar Basin, their trend changes back to about $47^{\circ} \mathrm{E}$ (Figure 6).

Close to the Madagascar Ridge the northeast-southwest trend of these fracture zones differs notably from the nearly north-south proposed Malagasy Fracture Zone, which has been traced parallel and along the east coast of Madagascar. Moreover, the contrast between the gentle upward eastern slope of the Madagascar Ridge and the steep eastern scarp of Madagascar is striking. It is clear from these observations, complemented by seismic reflection (Flexotir and airgun) profiles (Chapter 8 and Appendix I, this volume), that the north-south directional trend of eastern Madagascar cannot be traced southwards as proposed by several authors. For the same reasons, there is no evidence to consider the Madagascar Ridge as the southern extension of Madagascar and, therefore, a continental structure. It has not yet been established whether or not the northeastsouthwest trending fracture zones, which have been mapped throughout the Madagascar Basin, extend into the ridge. There are, however, several indices, from bathymetric and magnetic data, which do lead to this assumption. Consequently, it is possible to interpret the Madagascar Ridge as the southwestern continuation of the Madagascar Basin. The reason for its existence as a topographic elevation is unknown. Drilling results at Site 246 have shown that a shallow-water environment existed during late Paleocene and early Eocene. Subsidence of the sea floor occurred from early Miocene through Pliocene. Later, during the Quaternary, a possible uplift of the ridge is suggested to its present depth of about 1000 meters by the presence of shallow-water benthonic fauna in the sediments. 
TABLE 2

Magnetic Anomalies and Spreading Rates Associated with Ridges in the Northwestern Indian Ocean

\begin{tabular}{|c|c|c|c|c|}
\hline Anomaly & Location & Directional Trend & $\begin{array}{l}\text { Spreading (half) } \\
\text { Rate }(\mathrm{cm} / \mathrm{yr})\end{array}$ & Investigators \\
\hline $1-5$ & Central Indian Ridge & NW-SE & $\sim 2$ & Fisher et al. (1971) \\
\hline $1-5$ & Carlsberg Ridge & NW-SE & $\sim 1.2$ & $\begin{array}{l}\text { Cann and Vine (1966) } \\
\text { Vine (1966) } \\
\text { Le Pichon and Heirtzler (1968) } \\
\text { Fisher et al. (1968) }\end{array}$ \\
\hline $23-29$ & $\begin{array}{l}\text { Arabian Sea (north of } \\
\text { Carlsberg Ridge) } \\
\text { Somali Basin (south of } \\
\text { Carlsberg Ridge) } \\
\end{array}$ & $\begin{array}{c}\text { E-W } \\
\text { WNW-ESE }\end{array}$ & $\sim 6.5$ & $\begin{array}{l}\text { Matthews (1966) } \\
\text { Fisher et al. (1968) } \\
\text { McKenzie and Sclater (1971) }\end{array}$ \\
\hline $\begin{array}{r}22-30 \\
30-33 \\
\end{array}$ & $\begin{array}{l}\text { Central Indian Basin } \\
\text { between Chagos-Laccadive } \\
\text { and Ninetyeast ridges) }\end{array}$ & $\begin{array}{l}\sim \mathrm{E}-\mathrm{W} \\
\sim \mathrm{E}-\mathrm{W}\end{array}$ & $\begin{array}{l}\sim 8.0 \\
\sim 5.6\end{array}$ & McKenzie and Sclater (1971) \\
\hline $\begin{array}{r}5-16 \\
17-22 \\
23-27 \\
27-30 \\
30-33\end{array}$ & Central Indian Basin & $\begin{array}{c}\text { NW-SE } \\
\sim \text { WNW-ESE } \\
\sim \text { E-W } \\
\text { E-W } \\
\text { E-W }\end{array}$ & $\begin{array}{r}2.5 \\
4.0 \\
8.1 \\
12.0 \\
5.7\end{array}$ & Sclater and Fisher (in press) \\
\hline
\end{tabular}

TABLE 3

Magnetic Anomalies and Spreading Rates Associated with Ridges in the Southwestern Indian Ocean

\begin{tabular}{|c|c|c|c|c|}
\hline Anomaly & Location & Directional Trend & $\begin{array}{l}\text { Spreading (half) } \\
\text { Rate }(\mathrm{cm} / \mathrm{yr})\end{array}$ & Investigators \\
\hline $1-5$ & Southwest Indian Ridge & $\sim \mathrm{E}-\mathrm{W}$ & 1.0 & $\begin{array}{l}\text { Schlich and Patriat (1971a) } \\
\text { Bergh (1971) } \\
\text { McKenzie and Sclater (1971) }\end{array}$ \\
\hline $1-5$ & Southeast Indian Ridge & NW-SE & 3.4 & $\begin{array}{l}\text { Le Pichon and Heirtzler (1968) } \\
\text { Schlich and Patriat (1971b) }\end{array}$ \\
\hline $\begin{array}{r}5-5 c \\
5 d-6 a \\
6 a-17 \\
17-22 \\
23-27 \\
28-30 \\
31-33 \\
\end{array}$ & Crozet Basin & $\begin{array}{c}\text { NW-SE } \\
\text { NW-SE } \\
\text { NW-SE } \\
\text { WNW-ESE } \\
\text { WNW-ESE } \\
\text { WNW-ESE }\end{array}$ & $\begin{array}{r}2.0 \\
3.1 \\
\sim 2.5 \\
\overline{7} \\
\sim 7.8 \\
\sim 13.8 \\
\sim 5.6 \\
\end{array}$ & $\begin{array}{l}\text { Schlich and Patriat (1971b) } \\
\text { Schlich (in preparation) }\end{array}$ \\
\hline $\begin{array}{l}19-22 \\
23-27 \\
28-30 \\
31-33 \\
\end{array}$ & Madagascar Basin & $\begin{array}{l}\sim \mathrm{NW}-\mathrm{SE} \\
\sim \mathrm{NW}-\mathrm{SE} \\
\sim \mathrm{NW}-\mathrm{SE} \\
\mathrm{NW}-\mathrm{SE}\end{array}$ & $\begin{array}{r}\sim 4.0 \\
7.1 \\
12.2 \\
4.0\end{array}$ & $\begin{array}{l}\text { Schlich and Patriat (1971c) } \\
\text { Schlich et al. (1972b) } \\
\text { Schlich (this volume) }\end{array}$ \\
\hline $31-33$ & Mascarene Basin & NW-SE & 4.0 & Schlich (this volume) \\
\hline
\end{tabular}

\section{DRILLING RESULTS IN RELATION TO SEA-FLOOR SPREADING MAGNETIC ANOMALIES IN THE WESTERN INDIAN OCEAN}

Four sites in deep oceanic basins of the western Indian Ocean were drilled during Leg 25 of the Deep Sea Drilling Project: Site 239 in the southern Mascarene Basin, Site 240 in the central abyssal plain of the western Somali Basin, Site 245 in the southern Madagascar Basin, and Site 248 in the northwestern Mozambique Basin. The major objective of drilling at these sites was to establish the age of the basement in order either to check proposed sea-floor spreading magnetic patterns or to provide a guideline for future magnetic data interpretation.
Site 239 lies on the older side (south) of anomaly 31 (Figure 6), and is age dated, according to the Heirtzler et al. (1968) time scale as complemented by McKenzie and Sclater (1971), beyond anomaly 30 , at 72 million years (Schlich, this volume). The biostratigraphic age for the lowermost sediments recovered at the contact with the basaltic basement is late Campanian, which gives a minimum age of 71 to 73 m.y. (according to the time scale of Casey, 1964) for the underlying low-K tholeiitic basalt. The agreement between the magnetic time scale and the biostratigraphic age obtained from both the nannofossils and foraminifera appears surprisingly good.

Site 240 is located about 260 miles south of anomaly 28 , which has been identified by McKenzie and 


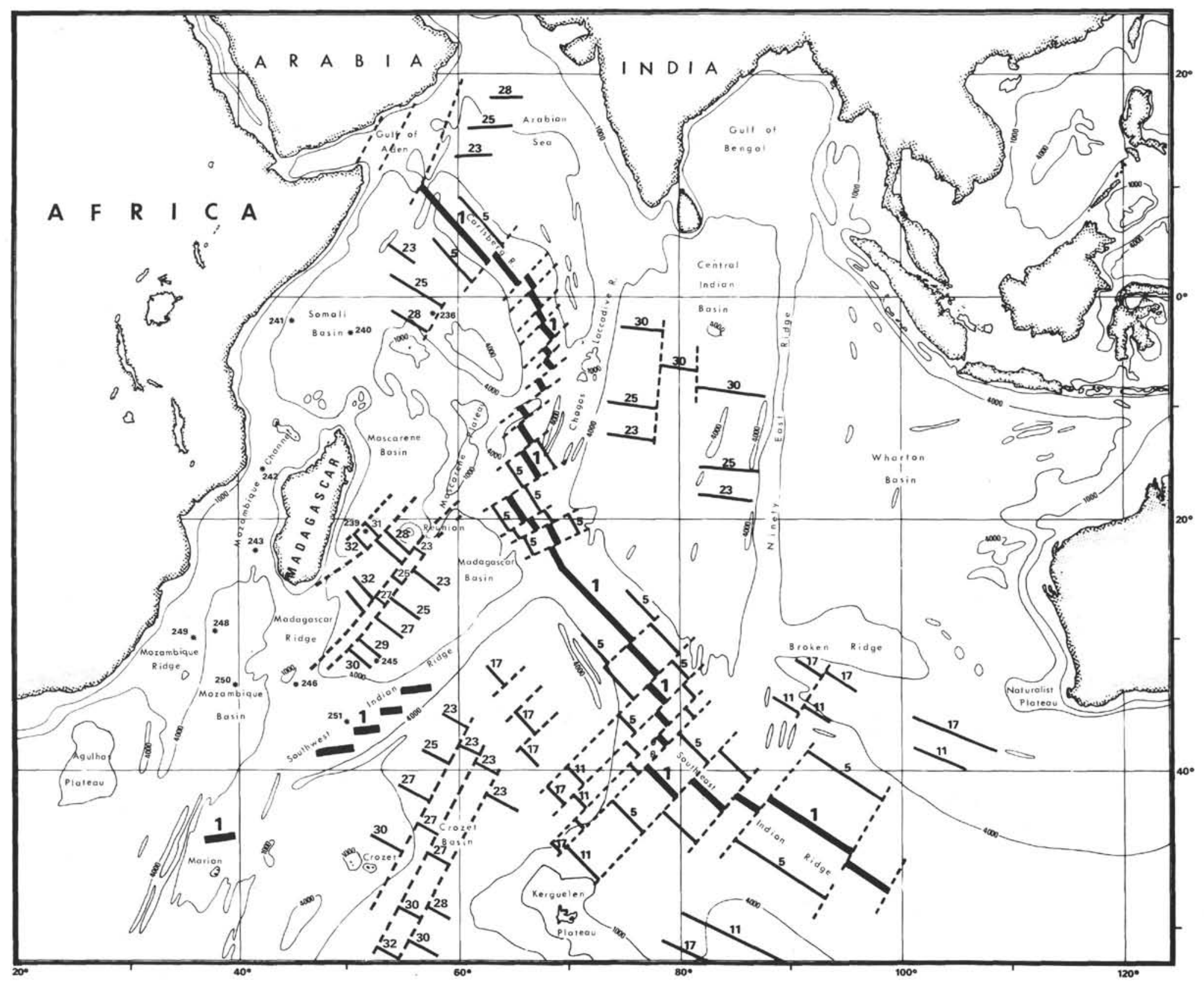

Figure 5. Magnetic lineations in the Indian Ocean; the axial magnetic anomalies are shown by thick heavy lines offset by fracture zones (dashed lines). The numbers refer to identified magnetic anomalies according to Heirtzler et al. (1968) time scale. The identifications north of the Mascarene Islands are from McKenzie and Sclater (1971); south of $20^{\circ} \mathrm{S}$ from Schlich and Patriat (1971 a, b, c) and Schlich (this volume). The results given in the Crozet Basin are provisional (Schlich, in preparation). 


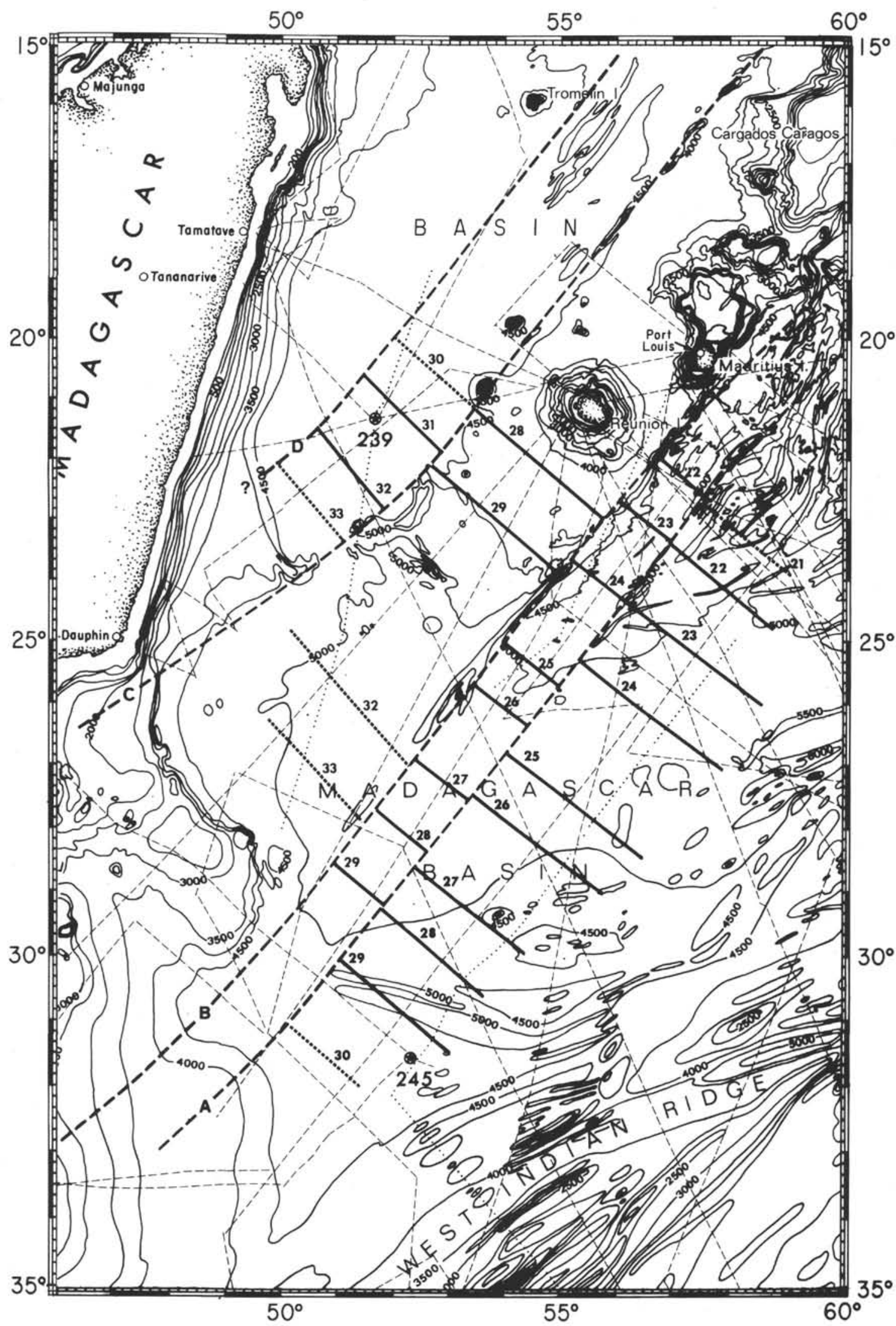

Figure 6. Fracture zones and magnetic lineations in the Madagascar and Mascarene basins (Schlich, this volume). 
Sclater (1971) north of the Seychelles Islands in the Somali Basin (Figure 5). If the proposed magnetic pattern is extrapolated to the south, Site 240 should be close to anomaly 32 , which formed about 75 m.y. B.P. The lowermost sediments at Site 240 have been dated as earliest Eocene (foraminifera) or latest Paleocene (nannofossils); a chalk inclusion in the basalt, with baked contacts, contains Eocene species. Since Site 240 appears to be located on a basement high (Site Report Chapter 3, this volume), it is most probable that the oldest deposits in that area were not sampled. Moreover, an intrusive origin for the basalt recovered cannot be excluded and this may also be used to explain the relatively youthful age of Site 240 . The basalt at this site was reached at a depth of about 5280 meters, but it is clear from seismic reflection profiles (Flexotir) obtained in the vicinity of Site 240 (Schlich et al., 1971a) that the mean basement depth in the area is at about 5400 meters. This depth corresponds, according to Sclater and Francheteau (1970) and Sclater and Harrison (1971), to an age of about 71/72 m.y., which would fit with the above mentioned extrapolation of the magnetic pattern in the Somali Basin. However, during Leg 24 in the northwestern Indian Ocean, Site 236 was drilled (Fisher, Bunce, et al., 1972) approximately 60 miles north of anomaly 28 , which was identified by McKenzie and Sclater (1971) in the Somali Basin. The basalt reached at a depth of 4793 meters at Site 236 is dated as pre-late Paleocene (57-58 m.y. [E. Vincent, pers. comm.]). This age is somewhat older than that which can be derived from the Sclater and Francheteau (1970) proposed depth versus age curve, but it is much younger than the suggested magnetic age of about $66 / 67$ m.y. obtained by assuming, as proposed by McKenzie and Sclater, a spreading (half) rate of $6.5 \mathrm{~cm} / \mathrm{yr}$.

Site 245 is located on the older side (south) of anomaly 29 (Figure 6) and is dated, according to the Heirtzler et al. (1968) time scale, at 69.5 m.y. (Schlich, this volume). The lowest sediments recovered are dated from the nannofossils and foraminifera as early Paleocene (middle Danian). Due to low recovery in the last core ( $1.4 \mathrm{~m}$ out of $9 \mathrm{~m}$ cored), it is probable that the basal sediment was not recovered. This would place the above age in error by about one million years if no hiatus occurs in the interval and gives for the oldest sediment a possible age of 62 to $64 \mathrm{~m} . \mathrm{y}$. (Berggren, 1972). This age is about 5 to 8 m.y. younger than the proposed magnetic age of 69.5 m.y. derived from the Heirtzler et al. (1968) time scale. A similar difference has been found by Sclater et al. (in press) at Site 213 in the Wharton Basin, which was drilled during Leg 22. Site 213 lies on the younger side (north) of anomaly 26, which corresponds to oceanic crust that formed 64 m.y. ago, but from biostratigraphic information, this basalt is age dated at 56 to 58 m.y. This difference is well established at Site 213 since nannofossils and foraminifera were found in sediment inclusions between the basaltic pillows. At Site 245, the difference of about 7 m.y. is somewhat doubtful since it has been proven by $\mathrm{K} / \mathrm{Ar}$ dating that the basalt is of intrusive origin. McKee (this volume) found a radiometric age of $27 \pm 3$ m.y. for the gray medium-grained diabasic basalt cored in the lower part of the hole, which leaves open the possibility of older sediments occurring deeper in the hole.
No clear magnetic anomaly pattern has been described nor observed in the Mozambique Basin, but it has already been suggested that this basin was one of the oldest in the western Indian Ocean. At Site 248, which is located about 30 miles east of the very steep flank of the Mozambique Ridge (Figure 5), basaltic basement was reached at a depth of 5428 meters. Due to poor recovery $(1.3 \mathrm{~m}$ out of $9 \mathrm{~m}$ cored), the basal sediments were not recovered, and based on the very poor nannofossil and foraminifera assemblages, an early Eocene or possibly late Paleocene (about 55 m.y.) age was suggested for the oldest sediments sampled. This age is surprisingly young taking into consideration the measured basement depth. McKee (this volume) dated the porphyritic basalt from the upper part of the basaltic section by the K/Ar method and found an age of 72 \pm 7 m.y., which fits much better with the observed basement depth and with a possible reconstruction of the Indian Ocean. During DSDP Leg 26, a second hole (Site 250) was drilled in the Mozambique Basin about 250 miles south-southeast of Site 248. The oldest dateable sediment, recovered 20 meters above the basaltic basement, gave an age of 81 m.y. (T. Davies, personal communication). The basement of this site was reached at 5844 meters. Thus, basement depths and ages at both sites (248 and 250) are consistent and lead to the tentative conclusion that the Mozambique Basin was probably formed during the first stages of the breakup of Gondwanaland.

In Summary, it is to be noted that the magnetic age derived for Site 239, in the Mascarene Basin from clearly identified magnetic anomalies is in remarkably good agreement with the biostratigraphic age obtained from both nannofossils and foraminifera found in the basal sediments. Consequently, it is clear from these results that the Heirtzler et al. (1968) magnetic time scale remains valid for Late Cretaceous time. For Site 240 , it is not possible to stress any definite conclusion, but considering the results of Leg 24 at Site 236, some further examination of magnetic data obtained in that area may be necessary. Regarding Site 245 , the possible difference of about 5 to 8 m.y. observed at that site between the magnetic age derived from the Heirtzler et al. (1968) time scale and the biostratigraphic age (Berggren, 1972), associated with similar observations made during previous DSDP legs, may suggest that the present magnetic time scale should be adjusted and made younger by a factor of about 7 percent for Paleogene time.

\section{THE RELATIONSHIP OF MADAGASCAR TO AFRICA}

The present status of knowledge and of speculation concerning the paleoposition of Madagascar and its possible horizontal movements relative to Africa has been summarized recently by Blant (1973) and in the site reports for Holes 242 and 243/244 in this volume.

Long before, and since, the development during the past decade of the sea-floor spreading hypothesis and plate tectonic concepts, three distinct predrift paleopositions and subsequent movements of Madagascar have been proposed:

1) Adjacent to eastern Africa off the coast of modern Somalia, Kenya, and Tanzania (du Toit, 1937, generally accepted by most other authors).

2) Adjacent to the pre-Cretaceous continental margin of Mozambique or Natal (Wellington, 1955, and many others). 
3) Present position relative to Africa maintained at least since the Paleozoic (Dixey, 1960, Holmes, 1965, and others). All of the above hypotheses continue to receive support in spite of the greatly improved state of knowledge of the structure, stratigraphy, and geological history of eastern Africa and Madagascar. Solution of this problem is most severely hampered by the almost complete lack of published data concerning the morphology, crustal structure, stratigraphy, and age of the Mozambique Channel and its deeper southward continuation as the Mozambique Basin, which is similarly flanked by the relatively high Mozambique and Madagascar ridges.

Some of the deep-sea drilling results and other appropriate marine geological and. geophysical data are briefly discussed here in an attempt to contribute constructively to the solution of this long-standing problem.

a) The Turonian ( $\sim 90$ m.y.) sediments at a subbottom depth of 1174 meters in Hole 241, located on the East African continental rise in 4-km-deep water and about 170 miles from the African coast, indicate that Madagascar has not occupied this position for at least the past $90 \mathrm{~m} . \mathrm{y}$. (cf. McElhinny, 1970).

b) The Davie Ridge is now identified as a continuous, seismically-active, structural lineament extending from near $10^{\circ} \mathrm{S}$ to at least as far south as $19^{\circ} \mathrm{S}$. By direct evidence from Site 242, the ridge has been the site of continuous pelagic sedimentation since the late Eocene ( 40 m.y.) and probably much longer. The north-south trend of the Davie Ridge is markedly transgressive to the northeasterly trending transcurrent fault (in the same latitude range) along which Madagascar is supposed by Flores (1970) to have moved away from Mozambique during the interval early Jurassic to Turonian. The direct evidence from Hole 242 is, therefore, not in conflict with the mechanism proposed by Flores although it does not lend support to his ideas.

c) Talwani (1962) proved from reconnaissance gravity measurements that the 2-3-km-deep Mozambique Channel is isostatically compensated and that the underlying crust cannot, therefore, be typical oceanic crust. For the same reason, it cannot be typical continental crust, and deep seismic refraction measurements are required to resolve this problem. The results of deep seismic reflection profiling have not yet been released for publication, but it can be said that they indicate a much more complex structure and sediment thickness than had previously been shown or considered to be the case. Perhaps the isostatically compensated Mozambique Channel is underlain by stretched and thinned continental crust and, having thus subsided, has been the site of continued sedimentation since that time.

d) The Mozambique Channel deepens progressively southwards into the 300-mile-wide Mozambique Basin. Seismic refraction measurements very close to the location of Site 248 have proved this to be the case (Ludwig et al., 1968). The basaltic basement at Site 248 has been isotopically dated at $72 \pm 7$ m.y. (McKee, this volume) which is of interest in that (i) this supports the suggestion by Kent (this volume) of possible structural continuity with flood basalts of the same age interbedded with Upper
Cretaceous sediments in the Morondava Basin of southeastern Madagascar, and (ii) it is much younger than the basaltic basement of Site 249 on the nearby Mozambique Ridge, which is at least as old as Neocomian and, therefore, possibly is connected with late- or post-Karroo volcanic activity in east southern Africa (see chapters by Vallier and Sigal in this volume) and possibly also in Madagascar. However, Erlank (this volume) has shown that the basaltic basement at Site 248 has closer geochemical affinities to the Karroo lavas than does the basalt from Site 249, which is more typically oceanic in composition. It is unfortunate, for the purpose of tectonic reconstruction, that basement was not reached by drilling at Sites $246 / 247$ on the Madagascar Ridge.

e) Figure 7 shows the morphology of the ocean floor along the track of Glomar Challenger between the Madagascar Basin and Durban. The morphology of the opposing steep scarps of the Madagascar and Mozambique ridges which flank the Mozambique Basin, and the abrupt bluff southerly terminations of both ridges at similar latitudes, are strongly suggestive of block faulting, and this speculation is illustrated by the insertion of hypothetical normal faults. However, the graben structure of the Mozambique Basin is improbable in view of its great width.

\section{MAJOR RESULTS AT SITES DRILLED, LEG 25}

This section is a synthesis of the major results that were obtained from each site drilled on Leg 25 . The reader should refer to Table 1 and Figure 2 for a review of drilling and coring data and the stratigraphic columns.

\section{Site 239}

Site 239 is located 180 miles east of Madagascar and 200 miles west of the island of Réunion, in a water depth of 4971 meters. The hole penetrated 320 meters of Pleistocene to Campanian sediments and 6 meters of the underlying basalt. The sediment column is divided into two major units; the older one (Unit II) is a seismically transparent layer that consists of Upper Cretaceous to middle Miocene brown clay, brown silty clay, and clayey nanno ooze. The younger unit (Unit I) forms a seismically stratified layer which includes middle Miocene through Pleistocene detrital silt and clay and nanno ooze.

Basalt forms the acoustic basement. Although specimens are altered, their chemistry is still typical of low- $\mathrm{K}$ tholeiites recovered from mid-ocean ridges, especially with regard to low $\mathrm{Ba}$ and $\mathrm{Nb}$ contents. Seawater apparently affected the chemistries by the additions of $\mathrm{K}$ and $\mathrm{Rb}$. An unusual feature is the low concentration of $\mathrm{Cr}$ and $\mathrm{Ni}$.

The age of the oldest sediment is late Campanian ( 71-73 m.y.). The site lies between anomalies 32 and 31 (Schlich, this volume); the corresponding age is $72 \mathrm{~m} . \mathrm{y}$. according to the Heirtzler et al. (1968) time scale, complemented beyond anomaly 30 by McKenzie and Sclater (1971).

Cretaceous and lower Paleocene sediments are represented by a thin sequence of brown clay and clayey nanno ooze. A hiatus marks the Maestrichtian and earliest Paleocene. Apparently the sea floor subsided (or CCD raised) before the onset of late Danian sedimentation (61-64 m.y.), after which, brown clay and brown silty clay 


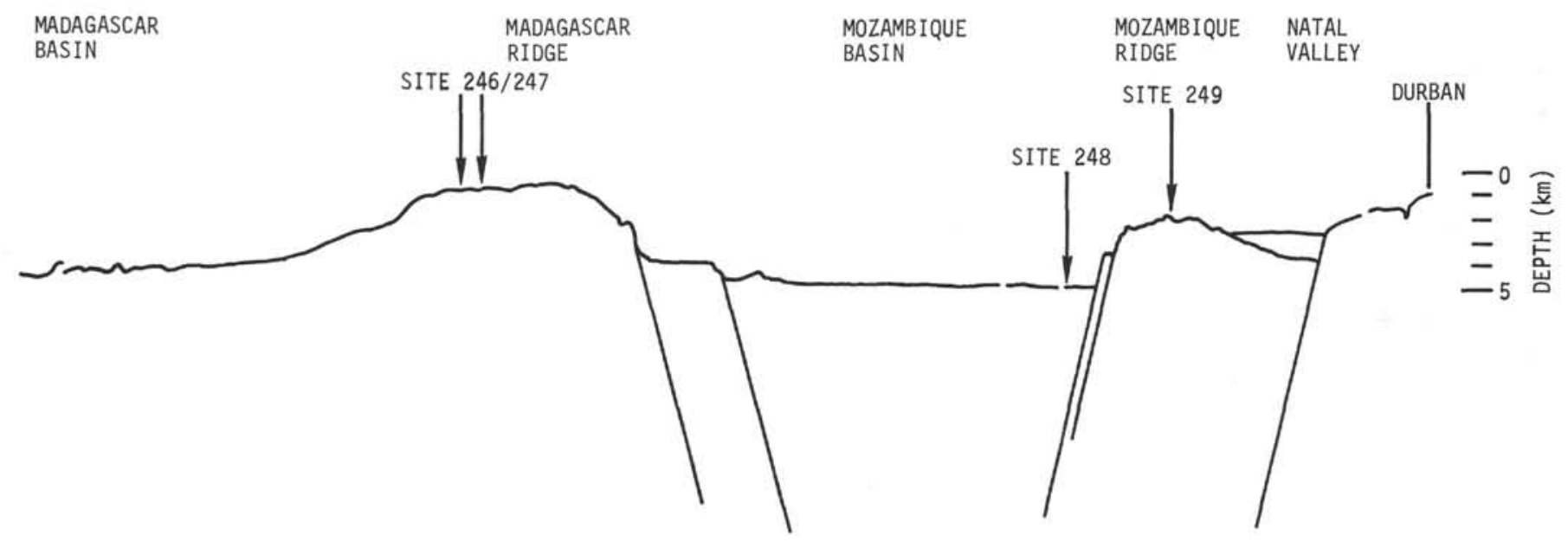

Figure 7. Sea-floor topography across the Madagascar Ridge, Mozambique Basin, and Mozambique Ridge.

became dominant for the remainder of the Paleogene. Another hiatus may mark parts of the late Paleocene and Eocene. However, the absence of cores in a 40-meter interval does not allow a definite conclusion to be made. There is a possibility that this interval is a condensed sequence and that sediments representative of these ages are present.

Terrigenous sediments reached the site throughout most of its history. Silt-sized minerals (mostly quartz and feldspar, but with some heavy minerals which include zircon, staurolite, hornblende, and garnet) occur in the brown clay-brown silty clay sequence (Unit II) and as distinct beds in Unit I. Strong terrigenous sedimentation, some of which was associated with turbidity current transport, began at least by the middle Miocene; it probably was associated with the uplift of Madagascar. The presence of displaced shallow-water (outer shelf) benthonic foraminifera support this interpretation.

Volcanism had only a small effect on the sediment column, which is somewhat surprising considering the site's proximity to Madagascar, the Mascarene Plateau, and the Mascarene Islands. Diagenesis of volcanic sediments contributed zeolites, montmorillonite, and possibly some palygorskite to the column.

At least 50 percent of the recovered sediments is pelagic in origin, with nannofossils being the major biogenic contributors. Apparently, productivity reached a maximum during the Miocene, when sedimentation rates reached 22 to $24 \mathrm{~m} / \mathrm{m}$.y. This Miocene productivity might be related to the onset of the equatorial circulation pattern which occurred after India moved across the Equator.

The geologic history reconstructed from the lithologies, fossils, and magnetics at Site 239 is consistent with the formation of sea floor at a spreading ridge and subsequent subsidence as the crustal slab cooled and moved away from the ridge. The further opening of the ocean with attendant initiation of cold Antarctic Bottom Waters (with their associated currents), and of an equatorial current system, affected both the biogenic productivity and the formation of hiatuses by current scouring and by raising the CCD. The epeirogenic uplift of Madagascar, probably in the early and middle Miocene, led to increased erosion, and, consequently, the detrital sediment dispersal.

\section{Site 240 (Holes 240 and 240A)}

Site 240 is located in the central abyssal plain of the western part of the Somali Basin, 500 miles from the African coast and 350 miles from the Seychelles Islands, in 5082 meters of water. Although technical difficulties greatly hindered the scientific results at this site, the two holes did provide data sufficient for some interpretations.

The sediment column is divided into two major units which overlie basalt. The upper unit (Unit I), about 160 meters thick, is composed of gray rad/nanno ooze, silt, and clay of late Miocene to Holocene age. The lower unit (Unit II), of early Eocene and middle Miocene age, is about 30 meters thick and consists of brown and yellow clay, silt, and sand with a basal layer of silt-rich nanno ooze.

Coarser grained beds of sand and silt in the terrigenous detrital sediments contain mineralogies that are characteristic of granitic terranes including quartz, microcline, garnet, amphibole, pyroxene, epidote, and tourmaline. These sands and silts plus the interbedded muds were derived most likely from the African continent and were transported to the site by turbidity currents. Displaced fauna in the basal calcareous unit indicate that it is a pelagic turbidite.

Dark gray basalt is fine grained and partly glassy with numerous fractures, calcite veins as much as $1 \mathrm{~cm}$ wide, and calcite-filled druses. Small inclusions of lower Eocene chalk, which have recrystallized contacts due to baking, occur in the lava. Chemistries are similar to average mid-ocean ridge tholeiitic basalt except for a relatively higher amount of $\mathrm{Cr}$, and lower $\mathrm{Sr}$ and $\mathrm{Zr}$ contents. Comparisons between fresh glass and whole rock chemistries suggest that seawater alteration has added $\mathrm{K}$, which now is six times more abundant in the rock than in the glass.

One major hiatus occurs in the column between the early Eocene (52-53.5 m.y.) and the late Miocene ( $\sim 10$ m.y.). The reasons for this hiatus are not known, but it may be related both to the formation of an erosive 
western boundary current that spilled over into the Somali Basin from the Mascarene Basin and to sediment starvation. Productivity in the upper waters, which increased after the initiation of the equatorial current system, is shown by the abundance of pelagic biogenous fossils in the Neogene sequence. Coarse sediments in the Eocene and the Miocene suggest that Africa was undergoing uplift at these times. Some middle Miocene faulting, along the coast in East Africa, did occur after the formation of a peneplain.

\section{Site 241}

Site 241 is located on the continental rise of East Africa, about 170 miles from the coast in the western part of the Somali Basin. Drilled in a water depth of 4054 meters, this hole penetrated 1174 meters of sediment, which makes it one of the deepest holes drilled by the Deep Sea Drilling Project.

The lithologic column can be broadly subdivided into two gradational units which range in age from Holocene to middle Cretaceous (Turonian/early Senonian). The top unit (Unit I), to a depth of about 470 meters, consists mainly of Holocene to upper Oligocene nanno ooze, silty clay, and clayey silt which contain minor amounts of radiolarians, diatoms, and foraminifera. Unit II is 704 meters thick and has middle Eocene to middle Cretaceous clay, claystone, and shale with minor amounts of nanno ooze, nanno chalk, siltstone, and calcareous quartz sandstone. This unit is almost devoid of fossils, particularly in the bottom parts, with only thin beds of nannofossils and sparse foraminifera which have wide age ranges.

Two hiatuses occur in the sequence. The older is from the Campanian (75.5-71 m.y.) to the late Paleocene (58-56 m.y.) and the younger is from the early Eocene ( $\sim 50 \mathrm{~m} . \mathrm{y}$.$) to the late Oligocene (26-24.5 m.y.). This$ younger hiatus is marked by a distinct change from older, almost totally terrigenous sediments to ones that have abundant calcareous biogenic components. This sharp increase in biogenous sediment, accompanied by increases in organic carbon in post-Miocene time, is related to increased productivity of the surface waters.

Terrigenous deposits in the column have heavy mineralogies that include hornblende, augite, olivine, garnet, zircon, epidote, sphene, rutile, apatite, and tourmaline, which indicate the erosion of granitic/ metamorphic and probably some volcanic terranes. Volcanic ash beds, now devitrified, occur in the Cretaceous near the base of the hole and cannot be correlated with known volcanism nearby in eastern Africa. However, they may be related to Madagascar volcanism which was quite extensive, both in the Turonian and in the Campanian.

The entire section penetrated represents the accumulation in a deep-water environment where the terrigenous and pelagic sediments that accumulated are characteristic of progressive outbuilding of the continental margin with a concomitant increase in biogenic productivity in the surface waters during the later stages. Relatively high sedimentation rates $(\sim 15 \mathrm{~m} / \mathrm{m} . \mathrm{y}$.$) and breaks in the sedimentary record$ can be tied both to epeirogenic movements of the African continent and continental margin and to the initiation of a current system that increased productivity in the surface waters. In the lower part of the interval, a flysch-like sequence was cored which includes both proximal and distal turbidite facies. These sediments probably accumulated as channel, levee, and overbank deposits of a migrating submarine distributary system at the base of the Cretaceous continental slope. In this regard, it is interesting to note that the sands at Site 240 are more proximal than those recovered at Site 241. If the sands at Site 240 were derived from Africa, as seems likely, they certainly bypassed the continental rise at Site 241 . Site 240 sands apparently were transported in localized distributary channels across the continental rise for subsequent dispersal onto the Somali Abyssal Plain.

The continental rise off East Africa near Kenya has remained essentially unchanged, except for some vertical movements, during the last 90 million years. From the evidence gathered at this site, it is not likely that Madagascar occupied a position adjacent to that part of Africa during that particular time interval.

\section{Site 242}

Site 242 is located in a water depth of 2275 meters along the eastern flank of the asymmetric and weakly seismic Davie Ridge (also called the Mozambique Fracture Zone), a north-south trending positive relief feature in the Mozambique Channel between Africa and Madagascar. The single hole penetrated 676 meters of upper Eocene to Holocene sediments, which were divided into three units on the basis of lithification and clay content.

The entire section consists dominantly of biogenic sediments of very similar composition which grade in age, apparently without break, from Holocene to early late Eocene, and physically from greenish-gray nanno ooze and nanno chalk to brown compacted nanno chalk. Foraminifera comprise as much as 25 percent of some samples in the younger parts of the hole but diminish in abundance with depth. The clay mineral content increases with depth and occurs as distinct layers, $2-5 \mathrm{~cm}$ thick, in the bottom unit.

The dominance of calcareous nannofossils plus the paucity of terrigenous detritus indicates that the site has been within a region of similar pelagic sedimentation since the late Eocene, which points to the region's tectonic stability for about the last 40 m.y.

The absence of any major hiatus in the column separates this site from the other pelagic sequences that were drilled on Leg 25. The reasons for the continuous and the high rates of sedimentation (average of about $20 \mathrm{~m} / \mathrm{m}$.y.) are not known. Probably, they are related to the high surface productivity of waters connected to the equatorial current system, and to the fact that the site has been above the CCD during its late Eocene to Recent history.

The absence of abundant terrigenous sediments in the section also is somewhat surprising, considering its proximity to East Africa and Madagascar. Apparently, the site has been protected from terrigenous influxes derived from Africa by the Davie Ridge, which acted as a barrier to the dispersal. Most detritus from Madagascar is deposited on the deeper Comoro Abyssal Plain and thus does not reach the shallower depths at Site 242. 
Acoustic basement, which was calculated to be at a depth of about 641 meters, is not marked by a distinct and sudden change in lithology. Rather, it corresponds to slight changes (increases in clay content and compaction) that occur in the 635- to 668-meter interval. This acoustic reflector can be traced to and identified on the Glomar Challenger airgun record as "basement" which forms the apparently sediment-free crest of Davie Ridge. In fact, recent deep seismic reflection data (Marion Dufresne 2, 1973) have shown several deeper reflectors at the site which were not reached by the 676-meter-deep hole.

Some previous workers have suggested that Madagascar moved along the Davie Ridge (Mozambique Fracture Zone) from East Africa to its present position. However, from our evidence, it seems just as logical to suggest that Davie Ridge is the result of still-active vertical tectonic movements which possibly are related to the East Africa rift valley system.

\section{Sites 243 and 244}

Sites 243 and 244 are located about five $\mathrm{km}$ apart in the Zambesi Canyon, whose floor lies about 600 meters deeper than the surrounding sea floor. The objectives of drilling deep into the canyon floor were not attained because of technical problems.

At Site 243 , one punch core was attempted with poor results. A small amount of coarse sand and fine gravel was recovered, and after a further penetration to 32 meters, the site was abandoned. At Site 244, only a core catcher sample was recovered, and after 27 meters of drilling, this site also was abandoned.

The sand and gravel indicate a crystalline (granitic/metamorphic) source rock terrane and that the materials are in transit towards the Mozambique Basin from Africa and Madagascar. Terrigenous debris, apparently, is fed into this deep canyon through the many submarine canyons that indent the continental margins of both Madagascar and Africa. Particularly evident is the relationship with the Zambesi submarine canyon which heads near the mouth of Zambesi River at Chinde on the coast of Mozambique.

\section{Site 245 (Holes 245 and 245A)}

Site 245 is located in the southern Madagascar Basin in a water depth of 4857 meters, about 300 miles east of the Madagascar Ridge crest and about 200 miles northwest of the Southwest Indian Ridge axis. It is beyond the apparent limit of oceanic crust formed by spreading from the latter ridge. Hole 245 was drilled and intermittently cored to a depth of 310 meters followed by continuous coring to 396.5 meters, including 7.5 meters penetration into the basaltic basement. A second complementary hole (245A) was drilled at the same location with nearly continuous coring between 20 and 150 meters.

In the 389-meter sediment section, four lithologic units were distinguished. The uppermost is 63 meters thick and consists of brown clay and brown silty clay. The unit is almost devoid of fossils because of calcite dissolution, but a sample from a depth of 16 meters yielded nannofossils of middle Miocene age, and poorly preserved nannofossils from the 54-63-meter interval are late Eocene in age. The lower units (2 through 4 ) provide a 326-meter thick, mostly biogenic, Paleogene sequence of early Paleocene to late Eocene age. Unit II is a 63-meter thick middle and upper Eocene sequence of variegated brown nanno-bearing clay interbedded with nanno ooze and brown silty clay. The upper Eocene Unit III consists of nanno ooze, 83 meters thick, and Unit IV (Paleocene/lower Eocene) is 181 meters thick and is mostly a nanno chalk with interbedded chert, devitrified volcanic ash, and a lower 20 meters of clay-rich nanno chalk that is black to dark brown in color because of high iron and manganese contents.

The lowermost sediments cored were confidently dated as early Paleocene (Danian) in age (61-63 m.y.). The last 9 meters of attempted core contained only 1.4 meters, thereby suggesting that as much as 7.5 meters of the oldest sediment may not have been recovered.

The uppermost fragment of recovered basalt is a 6-cm-long piece that is made up of two types of basaltic rock. Fine-grained glassy basalt and medium-grained diabase occur together in a somewhat obscure relationship. Contacts between the two rock types are sharp but the sequence of events is not clear. All other basaltic rock recovered in Hole 245 is diabasic, and is best described as a medium-grained diabase. The diabase is nonporphyritic and fairly fresh except near some fractures. Major and trace element data for this diabase show that it is very similar to the mid-ocean ridge tholeiites; low $\mathrm{K}$ and $\mathrm{Rb}$ concentrations are in accord with this interpretation. Noteworthy also is the relatively high $\mathrm{S}$ content inasmuch as $\mathrm{S}$ has been shown to be easily renewed during seawater alteration.

McKee (this volume) dated the diabase by K/Ar methods and found it to be $27 \pm 3$ m.y. old. This date indicates the intrusive nature of the rock.

The black and brown manganiferous basal sediments, of early Paleocene age, are chemically similar to some basal sediments in the Atlantic and Pacific oceans, as well as to those presently being deposited on the East Pacific Rise, except they have a lower metal content (Warner and Gieskes, this volume). The interbedded volcanic ashes in this sequence have a distinctive chemical signature; in places they are enriched with heavy metals.

One major hiatus occurs in the column between the upper Eocene sediments (42-38 m.y.) and the middle Miocene (12.5-11 m.y.). However, because its existence is based upon the absence of dateable fossils, this hiatus either may not exist or may be of much shorter length. Apparently, the CCD reached the sea floor at 4100 meters about 20 m.y. after the sea floor was created and has remained above until now (Leclaire, this volume). The formation of this hiatus probably is related both to calcium carbonate dissolution and to erosion by deep-water currents.

The data derived from studies of the sequence at Site 245 are consistent with an interpretation which fits models of sea-floor movements from a mid-oceanic ridge system. Oceanic crust formed at the Central Indian Ridge crest in early Paleocene (or possibly in latest Cretaceous). Pelagic biogenous sedimentation during the first stages of lateral movement was accompanied by volcanic and hydrothermal(?) activities which gave rise to interbedded volcanic ash layers and iron/manganese enrichment of sediments during at least the early Paleocene. Progressive lateral 
movement, accompanied by greatly increased biological productivity during the early Eocene, produced a thick section of Paleocene and lower Eocene nanno ooze. Compaction of the lower oozes formed chalk and selective silicification created thin chert beds. Sea floor continued to subside and approached the CCD in about the middle Eocene, when there was a sharp lowering of the sedimentation rate. An influx of terrigenous sediment at about this time suggests epeirogenic uplift of the nearest landmass, probably Madagascar. During the late Eocene, the sea floor reached the CCD and since that time only brown clay and brown silty clay have accumulated.

\section{Sites 246 and 247}

Sites 246 and 247 were drilled nine miles apart, near the crest of the Madagascar Ridge, about 480 miles south of Madagascar. Penetration at Site 246 was 203 meters below the sea floor in 1030 meters of water. This site was abandoned because of unstable hole conditions. An attempt to drill an alternative site (Site 247) also was abandoned because of the inability to penetrate a hard layer at a depth of 26 meters.

In spite of poor recovery at Site 246 , a geologic history can be proposed. The section is divided into three distinct units which range in age from early Eocene (possibly late Paleocene) to Recent. A hiatus of 25-27 m.y. occurs between the upper Eocene and upper Oligocene/lower Miocene sediments.

The uppermost unit (Unit I) is about 125 meters thick and is represented by Quaternary to lower Miocene foram ooze and subordinate nanno foram ooze. Unit II $(51 \mathrm{~m}$ thick) consists mostly of unconsolidated shelly calcareous sand, some glauconite-rich, which is characteristic of a shallow-water environment. This unit has an early Eocene or early middle Eocene age for all but the top few meters which are late Oligocene/early early Miocene in age. It is evident that an unconformity is present, which represents a hiatus of about 25 to 27 m.y., even though there is no apparent lithologic change. The lowest unit (Unit III), 18 meters thick, is dominated by unconsolidated glauconitic calcareous sand and shelly/zeolite-rich volcanic sand with subordinate thin beds of lithified volcanic sandstone and volcanic breccia; silty clay, limestone, and volcanic ash are present in minor amounts. The oldest sediment recovered, from a depth of 194 meters, is early early Eocene in age, possibly even latest Paleocene ( $\sim 53$ m.y.).

A unique heavy mineral assemblage in the lower parts of the sediment section indicates both crystalline complexes and volcanic terranes (Girdley and White, this volume). Significant heavy minerals are tourmaline, sillimanite, and titaniferous augite. Most of these heavy minerals no doubt were transported to the site from southern Madagascar although the possibility must be considered that parts of the Madagascar Ridge itself may have served as a source terrane for these materials.

Volcanogenic sediments have been altered extensively to zeolites and smectites although a large amount of relatively fresh glass remains. These sediments, some of which are cross bedded and contain fragments of glauconite, either were erupted in shallow water or were erupted subaerially and subsequently transported through shallow water to the site.

The following geological history is indicated from studies of the cored sequence. In the older units (II and III), the occurrences of shallow-water benthonic fauna, crossbedded volcanic sands, and glauconite suggest that the sediments were deposited in a moderately high energy, shallow-water environment during the early Eocene (and latest Paleocene?). Terrigenous sediments in very small amounts, derived from volcanic and crystalline terranes, also were deposited. A 25-27 m.y. hiatus followed the early Eocene shallow-water sedimentation. Reworking of these lower Eocene sediments occurred in the early Miocene. Apparently, subsidence of the sea floor commenced during the early Miocene and continued during the Pliocene, when mostly planktonic biogenic sediments were deposited. During the Quaternary, the addition of a considerable amount of shallow-water benthonic fauna suggests the formation of a shallow-water environment in the vicinity and possibly also an uplift of the site area to its present depth of about 1000 meters.

\section{Site 248 ,}

Site 248 is located in a water depth of 4994 meters in the northwestern Mozambique Basin, about 30 miles from the very steep eastern boundary scarp of the Mozambique Ridge. The hole penetrated 422 meters of middle Paleocene to Pleistocene sediments and 12 meters of the underlying basalt.

The stratigraphic column is divided into three units which overlie the basalt. Unit I (Pleistocene-middle Miocene in age) is about 300 meters thick and consists mostly of terrigenous sediments that include sand, silt, and clay. Some nanno ooze occurs near the top in the younger sediments. The coarse-grained sediments, which are associated with displaced shallow-water benthonic fauna, are particularly more abundant in the Miocene at the bottom of this unit. Unit II is a 107-meter-thick, gray-green laminated sequence of silty clay and volcanic clay that is probably mostly of early Eocene age. Unit III, about 15 meters thick, is of late Paleocene(?) and early Eocene age and consists predominantly of brown clay and brown silty clay.

Some 3.6 meters of basalt were recovered below the brown clay unit. The rock is coarsely porphyritic with some plagioclase phenocrysts up to $12 \mathrm{~mm}$ in length. Groundmass textures change from glassy near the top to diabasic at the bottom. Substantial amounts of $\mathrm{K}$ and $\mathrm{Rb}$ were added to the basalt during submarine weathering. Higher concentration levels of some elements that are not susceptible to seawater alteration (e.g., $\mathrm{Ti}, \mathrm{Ba}, \mathrm{Sr}, \mathrm{Ga}, \mathrm{Zr}$, and $\mathrm{Nb}$ ) fall within the range observed for Karroo lavas in the Lebombo area of East Africa and for tholeiites from Hawaii and Iceland (Erlank and Reid, this volume). Apparently, the lavas at Site 248 were derived from source areas which are less depleted in these elements (more primitive?) than most other abyssal tholeiites. The age of this basalt, based on $\mathrm{K} / \mathrm{Ar}$ dating of the plagioclase phenocrysts, is $72 \pm 7$ m.y. according to McKee (this volume). 
Unit III, the brown clay and brown silty clay unit, is enriched in iron and manganese but, surprisingly, not in $\mathrm{Cu}$, $\mathrm{Co}, \mathrm{Mo}$, and $\mathrm{Ni}$, as expected. Possibly, the relative mobility of the ions has a strong effect on the final concentrations (see Marchig and Vallier, this volume).

Unit II, the laminated volcanic clay-silty clay sequence, contains abundant authigenic minerals whose origins are tied to volcanism and possibly to the accumulation of siliceous fossils. Cristobalite, tridymite, clinoptilolite, and palygorskite are dominant in most X-ray samples. These partly volcanogenic sediments are the same age as the Eocene volcanic sediments on Madagascar Ridge (Site 246), which suggests that they may be related. Perhaps the volcanic sediments at Site 248 were derived from the same terrane that produced those at Site 246.

Thick massive sands occur in the lower part of Unit I, mostly in the middle late Miocene. No doubt, these were supplied by turbidity currents from Africa and Madagascar via the Zambesi Canyon. A thick Miocene and Pliocene distal facies of Unit I occurs farther south in the Mozambique Basin at Site 250 (T. Davies, personal communication). The thick terrigenous sediment accumulation in the Mozambique Basin probably is related to late Cenozoic epeirogenic uplift of Africa and Madagascar.

Two hiatuses are suspected, but the lack of good paleontologic control makes exact age assignments difficult. The first may lie in the Late Cretaceous-late Paleocene between the basalt and the oldest recovered sediment. A second, more strongly suspected hiatus is between the lower Eocene and middle Miocene sediments.

\section{Site 249}

Site 249 was drilled near the crest of the Mozambique Ridge, in a water depth of 2088 meters, about 80 miles west of Site 248. The hole penetrated 408 meters of sediment, mostly of Cretaceous and Miocene ages, and 4 meters of basalt.

The stratigraphic column is divided into three major units which overlie basalt. Unit I consists of 172 meters of gray foram-rich nanno ooze that has minor silt-bearing intervals. Chalk increases in abundance with depth and becomes the dominant lithology of Unit I below 159 meters. Only 1.7 meters of Pleistocene sediments overlie lower Pliocene, upper Miocene, and upper middle Miocene sediments. Unit II (Campanian and Maestrichtian in age) is composed of clay-rich nanno chalk and is 115 meters thick. The contact between the two units coincides with the hiatus that occurs between the late Maestrichtian and the late middle Miocene. At a depth of 287 meters, Campanian chalk rests unconformably on siltstone, claystone, limestone, and tuff on Unit III. Unit III is poorly dated but sparse fossil assemblages do give ages of Cenomanian or late Albian, Aptian or Barremian, and Neocomian (at least as old as Valanginian) to parts of the column. This unit is 121 meters thick and is black to dark brown in color because of an abundance of carbon and pyrite. The upper part of the unit is strongly volcanogenic, whereas the bottom part is dominantly terrigenous. Some silt-rich limestones occur throughout the unit as thin beds.

The acoustic basement is glassy, highly vesicular, and weathered basalt. Samples are similar in chemical composition to average mid-ocean ridge tholeiites. Moderate alteration is shown by the high $\mathrm{H}_{2} \mathrm{O}, \mathrm{K}$ and $\mathrm{Rb}$ contents, the high $\mathrm{Fe}_{2} \mathrm{O}_{3} / \mathrm{FeO}$ ratios, and the low $\mathrm{S}$ contents, all of which are consistent with the development of secondary clay minerals. The Site 249 basalt is chemically less similar to Karroo lavas than the basalt at Site 248. However, before any additional interpretations are made concerning the petrogenesis of these lavas, it is necessary to analyze more samples and to learn more about trace element relationships in basaltic rocks. It is unfortunate that neither the age of the basalt nor the age of the oldest sediment are known.

Extensive volcanism occurred at the time represented by sediments in the upper part of Unit III (AptianCenomanian?). Volcanic sediments are tuff, sandstone, siltstone, and claystone. Sigal (this volume) notes that no contemporaneous volcanism is recorded in either Africa or Madagascar which suggest that local vents, along what is now the Mozambique Ridge, may have contributed the volcanic materials.

Two major hiatuses occur in the sediment column. The older hiatus lies between the early Cenomanian ( $~ 97$ m.y.) and the late Campanian (71-73 m.y.) and the younger one is between the late Maestrichtian ( $65-68$ m.y.) and the middle Miocene (14-14.5 m.y.). Because of the absence of dateable fossils, both the time limits and the length of time represented by the older hiatus are not precisely known and should be reevaluated after more study. In fact, within the lower Cretaceous itself, several hiatuses may be present. The upper hiatus is better documented and may be related to the formation of a strong erosive current over the ridge in the middle Tertiary. A third hiatus may occur in the lower Pliocene-Pleistocene interval.

\section{REFERENCES}

Baker, B. H., 1963. Geology and mineral resources of the Seychelles Archipelago: Geol. Surv. Kenya, Mem. no. 3.

Baker, B. H. and Miller, J. A., 1963. Geology and geochronology of the Seychelles Islands and structure of the floor of the Arabian Sea: Nature, v. 199, p. 346-348.

Berggren, W. H., 1972. A Cenozoic time scale-some implications for regional geology and paleobiogeography: Lethaia, v. 5, p. 195-215.

Bergh, H., 1971. Sea floor spreading in the southwest Indian Ocean: J. Geophys. Res., v. 76, p. 6276.

Blant, G., 1973. Structure et paleogeographie du littoral meridional et oriental de l'Afrique. In Blant, G. (Ed.), Sedimentary basins of the African coasts. Part 2, South and east coasts: Assoc. African Geol. Surv., Paris.

Cann, J. R. and Vine, F. J., 1966. An area on the crest of the Carlsberg Ridge: petrology and magnetic survey; Roy. Soc London Phil. Trans. v. 259, p. 198-217.

Casey, R., 1964. The Cretaceous period. In Harland, W. B., Smith, A. G., and Wilcock, B., The Phanerozoic time scale: Geol Soc. London Quart. J., Suppl. 1, p. 193-202.

Davies, T. A., Luyendyk, B. P., Rodolfo, K. S., Kempe, D. R. C., McKelvey, B. C., Leidy, R. D., Horvarth, G. J., Hyndman, R. D., Thierstein, H. R., Boltovskoy, E., and Doyle, P., 1973. Across the southern Indian Ocean aboard Glomar Challenger: Geotimes, v. 18, no. 3 p. 16-19. 
Dixey, F., 1960. The geology and geomorphology of Madagascar and a comparison with eastern Africa: Geol. Soc. London Quart. J., v. 116, p. 255-268.

du Toit, A. L., 1937. Our wandering continents: Edinburgh (Oliver and Bovd).

Fisher, R. L., Bunce, E. T., Cernock, P. J., Clegg, D. C., Cronan, D. S., Damiani, V. V., Dmitriev, L., Kinsman, J. R., Roth, P. H., Thiede, J., and Vincent, E. S., 1972. Deep Sea Drilling Project in Dodo land, Leg 24: Geotimes, September 1972, p. 17-21.

Fisher, R. L., Engel, C. G., and Hilde, T. W. C., 1968. Basalts dredged from the Amirante Ridge, western Indian Ocean: Deep-sea Res., v. 15, p. 521-534.

Fisher, R. L., Johnson, G. L., and Heezen B. C., 1967. Mascarene Plateau, western Indian Ocean: Geol. Soc. Am. Bull., v. 78, p. 1247-1266.

Fisher, R. L., Sclater, J. G., and McKenzie, D. P., 1971. Evolution of the Central Indian Ridge, western Indian Ocean: Geol. Soc. Am. Bull. v. 82, p. 553-562.

Flores, G., 1970. Suggested origin of the Mozambique Channel: Geol Soc. S. Africa Trans., v. 73, p. 1-16.

Heirtzler, J. R., Dickson, G. O., Herron, E. M., Pitman, W. C., and Le Pichon, X., 1968. Marine magnetic anomalies, geomagnetic field reversals, and motions of the ocean floor and continents: J. Geophys. Res., v. 73, p. 2119-2136.

Holmes, A., 1965. Principles of physical geology (2nd Edition): Edinburgh (Oliver and Boyd).

Langseth, M. G. and Taylor, P. T., 1967. Recent heat flow measurements in the Indian Ocean: J. Geophys. Res., v. 72 , p. $6249-6260$.

Laughton, A. S., Matthews, D. H., and Fisher, R. L., 1970. The structure of the Indian Ocean. In Maxwell, A. E. (Ed.), The Sea: v. 4, p. 543-586.

Le Pichon, X. and Heirtzler, J. R., 1968. Magnetic anomalies in the Indian Ocean and sea-floor spreading: J. Geophys. Res., v. 73, p. 2101-2117.

Ludwig, W. J., Nafe, J. E., Simpson, E. S. W., and Sacks, S., 1968. Seismic refraction measurements on the southeast African continental margin: J. Geophys. Res., v. 73, p. 3707-3719.

Ludwig, W. J., Nafe, J. E., Simpson, E. S. W., and Sacks, S., 1968. Seismic refraction measurements on the southeast African continental margin: J. Geophys. Res., v. 73, p. 3707-3719.

Matthews, D. H., 1966. The Owen Fracture Zone and the northern end of the Carlsberg Ridge: Roy. Soc. London Phil. Trans., v. 259, p. 172-186.

Matthews, D. H. and Davies, D., 1966. Geophysical studies of the Seychelles Bank: Roy. Soc. London Phil. Trans. A., v. 259 , p. $227-239$.

McElhinny, M. W., 1970. Formation of the Indian Ocean: Nature, v. 228, p. 977-979.
McKenzie, D. P. and Sclater, J. G., 1971. The evolution of the Indian Ocean since the Late Cretaceous: Astron. Soc. Geophys. J., v. 25, p. 437-528.

Schlich, R., Aubertin, F., Delteil, J., Leclaire, L., Magnier, P., Montadert, L., Patriat, P., and Valery, P., 1972a. Données nouvelles sur le substratum du Bassin de Somalie a partir d'un profil de sismique reflexion: Compt. Rendus Acad. Sci. Paris, v. 275, p. 1331-1334.

Schlich, R., Delteil, J. R., Moulin, J., Patriat, P., and Guillaume, R., 1971. Mise en évidence d'une sédimentation de marge continentale sur le plateau de Kerguelen-Heard: Compt. Rendus Acad. Sci. Paris, v. 272, p. 2060-2063.

Schlich, R. and Patriat, P., 1971a. Mise en évidence d'anomalies magnétiques axiales sur la branche ouest de la dorsale médioindienne: Compt. Rendus Acad. Sci. Paris, v. 272, p. 700-703.

Schlich, R. and Patriat, P., 1971b. Anomalies magnétiques de la branche Est de la dorsale médio-indienne entre les iles Amsterdam et Kerguelen: Compt. Rendus Acad. Sci. Paris, v. 272, p. 773-776.

Schlich, R. and Patriat, P., 1971c. Expansion des fonds óceaniques dans l'Océan Indien Austral: Communication présenteé a la XV: Assemblée Générale de 1'UGGI, Moscow.

Schlich, R., Patriat, P., and Ségoufin, J., 1972b. Compterendu d'activité pour la periode du ler Avril 1971 au 29 Février 1972: Note IPG de Paris no. 46.

Sclater, J. G. and Fisher, R. L., in press. The evolution of the east central Indian Ocean with emphasis on the tectonic setting of the Ninetyeast Ridge: Geol. Soc. Am. Bull.

Sclater, J. G. and Francheteau, J., 1970. The implications of terrestrial heat flow observations on current tectonic and geochemical models of the crust and upper mantle of the earth: Roy. Astron. Soc. Geophys. J., v. 20, p. 509-542.

Sclater, J. G. and Harrison, C. G. A., 1971. Elevation of mid-ocean ridges and the evolution of the Southwest Indian Ridge: Nature, v. 230, p. 175-177.

Sclater, J. G., Jarrard, R. D., and Gartner, S., in press. Comparison of the magnetic and biostratigraphic time scales since the Late Cretaceous. In von der Borch. C. C., Sclater, J. G., et al., Initial Reports of the Deep Sea Drilling Project, Volume 22: Washington (U.S. Government Printing Office).

Talwani, M., 1962. Gravity measurements on HMS Ackeron in South Atlantic and Indian oceans: Geol. Soc. Amer. Bull., v. 73, p. 1171-1182.

Vine, F. J., 1966. Spreading of the ocean floor: new evidence: Science, v. 154, p. 1405-1415.

Wellington, J. H., 1955. Southern Africa: a geographical study: Cambridge (Cambridge Univ. Press). 